'Those, that die by reason of their madness': dying insane in London, I629-I 830 Reprints and permission: sagepub. co.uk/journalsPermissions.nav DOI: I0.I I77/0957I54XI |428930

hpy.sagepub.com

\title{
Jeremy Boulton
}

Newcastle University

\section{John Black}

Newcastle University

\begin{abstract}
Dying insane provoked 'great fear, and apprehension' in the minds of men and women. Death as a lunatic disrupted deathbed performance and rendered the victim incapable at law. This article examines lunacy as a cause of death in the metropolis between 1629 and 1830. It draws on new material from the admission registers of St Luke's Hospital, existing data from Bethlem and the London Bills of Mortality and unique biographical data on pauper lunatics dying in the parish of St Martin in the Fields. The article argues that lunacy being ascribed as a cause of death had a distinctive chronology in this period. Those most vulnerable to the stigma of lunacy at death were those dying as parish paupers and those who inhabited metropolitan institutions.
\end{abstract}

\section{Keywords}

Bills of Mortality, cause of death, England, pauper lunatics, private madhouses, searchers

\section{Introduction: lunatics in the London Bills of Mortality}

John Graunt, ${ }^{1}$ the seventeenth-century statistician and one of the founders of modern demography, was highly sceptical of the veracity of the numbers of deaths caused by lunacy recorded in the London Bills of Mortality, observing they were 'but few, viz. 158 in 229250'; many cases, except those in the Bethlem lunatic hospital, were unreported or deliberately misdiagnosed for some other disease (Graunt, 1662: 222).

This reported under-representation of insanity as a cause of death may not have been surprising to Graunt's contemporaries. Dying mad was to be avoided in the seventeenth century. Death by lunacy was included in his list of those 'more formidable, and notorious diseases', along with

\section{Corresponding author:}

John Black, School of Historical Studies, Armstrong Building, Newcastle University, Newcastle upon Tyne, NEI 7RU, UK. Email:john.black@newcastle.ac.uk 
sudden death, seizures, epilepsy, and death on the operating table, of which 'many persons live in great fear, and apprehension' - conditions that would have prevented an adult meeting their maker in a suitable frame of mind (Graunt, 1662). Dr William Black, the London physician and medical statistician, believed that insanity was an equally unwelcome companion to death in the eighteenth century. ${ }^{3}$ For Black, 'many lunatick deaths in London are not reported, from their being interred in dissenting and unregistered burying grounds, or in other places of interment without the verge of the bills', with some deaths from lunacy 'intentionally suppressed', and a 'considerable remnant, perhaps as many more, sunk amongst the suicides and drowned' (Black, 1789: 128-9). Lunacy could disrupt a good deathbed performance through which the pious, and often impious, would prepare for salvation after death, though itself considered of diminishing importance in the eighteenth century (Houlbrooke, 1998). Those making wills usually thanked God for being of sound mind, memory and understanding. Lunatics, those clearly of unsound mind, were of course unable to make valid wills, and signs of mental incapacity were cited frequently in probate disputes by hopeful claimants (Burn, 1767: 43, 45; see also: Bonfield, 1997; Houlbrooke, 1998: 80, 90, 218-19).

Although there is an extensive literature on the care of insane in the eighteenth-century metropolis, few scholars have investigated the concerns of Graunt and Black (Andrews and Scull, 2001, 2003; Murphy, 2001a, 2001b; Smith, 2007; Suzuki, 1991, 1992, 1998). This article addresses these contemporary fears of the under-representation of lunacy as cause of death in seventeenth- and eighteenth-century London and shows, initially, that insanity being ascribed as a cause of death had a distinctive chronology in this period. It argues that the process of the reporting of the cause of death in the Bills of Mortality was vulnerable to outside influence, which in turn could determine what diagnoses would be recorded. Andrews (1991: 499-505) and MacDonald (1981: 145-6) have expressed the possibilities of confusion in the diagnoses and recording of the cause of death of the insane in the eighteenth century. We argue that, to a significant extent, this misdiagnosis, and misreporting, was deliberate, in order to avoid the stigma of the dead being labelled 'lunatic' at the time of death, or the cause of death being ascribed as 'lunacy'. Furthermore, it was the pauper insane and those who died in metropolitan institutions who were most likely (though not always) to be characterized as being insane at death, or their mortality being brought on by insanity. Just as Andrews and Scull (2001:119-41) have identified that the wealthy could have the treatment of their insane family members and friends obscured to avoid any stigma or dishonour that the diagnosis of the insanity may have caused, we explore the extent to which those of the insane dead, or their friends and relatives who possessed greater wealth or social position, could often influence the reporting of cases of lunacy such that the cause of death was hidden or disguised.

Contemporary diagnoses and reporting of the death of the insane did not always distinguish between lunacy as a direct cause of death, and the death of a lunatic, whether caused by lunacy or some other illness (Andrews, 1991: 502-3). This is particularly apparent among the parochial burial records. In the St Martin in the Fields Sexton's Day Books and the St Luke Old Street Parish Burial Registers, for example, the terms 'Lunatick' and 'Lunacy' appear to be interchangeable in defining the cause of death of the insane throughout the eighteenth and early nineteenth centuries (COWAC, SDB, 1747-1812; LMA, BBR, 1747-1812; LMA, BR, 1807-27). Similarly, in the parish burial registers of St Botolph Bishopsgate and St Stephen Coleman Street the insane were recorded as having 'Died lunatic in Bedlam', but others are said to have 'Died of Lunacy in Bedlam'. In contrast, the Bills of Mortality define only 'lunacy' as a cause of death (Andrews, 1991: 502). In our study we will try to avoid any ambiguity in analysis that these factors may cause.

The starting point for any examination of the suppression, or not, of the reporting of death caused by insanity must begin with the statistics contained in the Bills of Mortality (Marshall, 1832). Figure 1 demonstrates the degree to which lunacy was recorded as a cause of death in the 


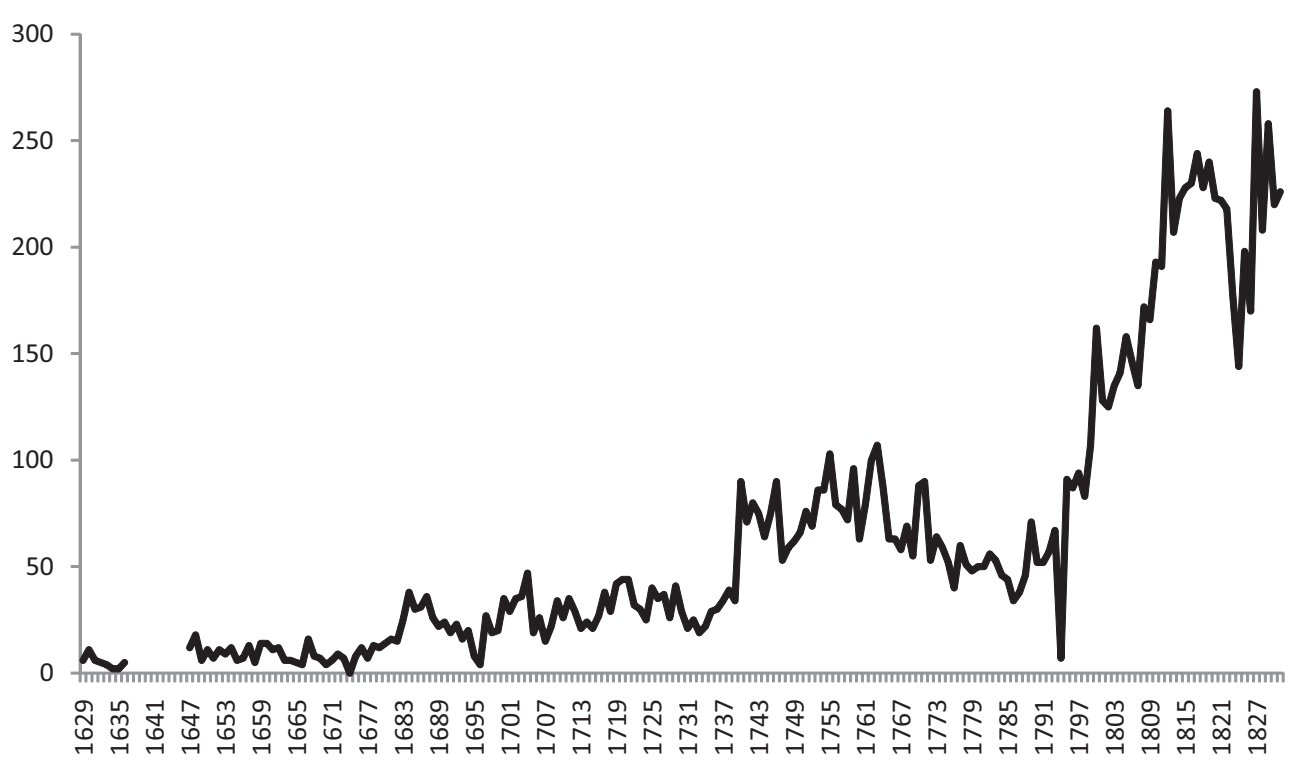

Figure I. Numbers of deaths caused by 'Lunacy' in the London Bills of Mortality, 1629-1831 (source: Marshall, 1832)

London Bills of Mortality between 1629 and 1831. Reported deaths from lunacy gradually increased from the mid-seventeenth century until the 1730s, doubled between the 1730s and the early 1760s, fell back somewhat in the 1780s and 1790s, and then dramatically increased. By the second and third decades of the nineteenth century it was common for more than 200 dead lunatics to appear in the London Bills in any one year. Although London had been growing rapidly from the middle of the eighteenth century, the dramatic increase in reported death by lunacy cannot be explained simply by the growth of the population. Death rates across the metropolis were falling from the late eighteenth century, and an increasing number of the capital's dead were being interred in places and grounds not covered by the Bills of Mortality. To understand the meaning behind the incidence of deaths from lunacy requires an in-depth investigation of the treatment of lunatics at the end of their life. We need to start with how, and to what extent, the badge of lunacy was applied to the metropolitan dead in the London parishes. We will proceed to examine the deaths from lunacy in London's two public hospitals for the insane, before investigating the treatment of the insane and the recording of their deaths in the large and socially varied West End Parish of St Martin in the Fields, using the databases generated by the ongoing Pauper Biographies Project. ${ }^{4}$

\section{Labels, searchers and lunatics}

How one was supposed to have died could matter a great deal in the eighteenth century (Dobson, 1997: 223-86). Causes of death that carried implications about the behaviour and reputation of the deceased might be concealed with euphemisms. In the reporting of other deaths such as executions, claimed one authority, the London Bills of Mortality were particularly 'shamefully erroneous and defective'. ${ }^{5}$ Alternatively some diseases were seen as signifying an elevated life-style. Analysis of the St Martin's Sextons' Day Books is revealing here. Other 'life-style' causes of death, notably deaths from 'foul disease' and gout, are known to have been attributed almost exclusively to 
particular social groups (Porter and Rousseau, 1998). Almost all those reported as dying of 'foul', that is venereal, disease, turn out to have been paupers buried from the parish workhouse (Siena, 2004: 136, 170-2, 177-80, 260). Those lacking resources or family members able to intervene were especially vulnerable to such shaming or contentious labelling post-mortem. Conversely, it was extremely rare for those dying of 'gout', a condition commonly associated with high-status over-consumption, to be drawn from the ranks of the poor. Gout was a sort of inverse status symbol: those reported as dying of the condition paid some of the highest burial fees in the parish (Black, 1789: 87; see also: Boulton and Schwarz, 2012; Razzell and Spence, 2006).

Each death in London, and its cause, was to be reported initially by searchers. The searchers, usually two elderly women licensed by the Bishop of London, in receipt of parish aid and often ex-parish nurses or midwives, viewed each body and returned the cause of death among other details to the parish clerk, who in turn would transmit the information to the London Parish Clerk's Company (Siena, 2011:130-3). Through a process of questioning any medical attendants who witnessed the death, talking to the friends and family of the deceased, and their own experience of physiological symptoms, searchers had to distinguish the cause of death (Graunt, 1662: 11). The searchers were supposed to receive a small fee (a groat, $4 \mathrm{~d}$.) for this service from the family of the deceased. The poor were not expected to pay these fees. The parish of St Martin's paid its two searchers a monthly salary of $13 \mathrm{~s}$. to view the corpses of the poor in the later eighteenth century. One would expect that those paying fees were more likely to be able to influence the return. ${ }^{6}$

Most of those who wrote about the London Bills assumed searchers were bribed routinely to conceal or misreport deaths and that in some cases they did not even view the corpse. William Black was especially dismissive about what he called 'this ceremony of inspection by the searchers', asserting they would '... negligently enquire from the relations the name of the disease, adding the age and sex: or sometimes they are stopped in the hall, and dismissed without any scrutiny' (Black, 1789: 254-5). ${ }^{7}$

Graunt, over 100 years earlier, questioned the numbers reported by parish clerks as having died from venereal disease. He contended that searchers would often ignore obvious physiological signs of death caused by venereal disease, under the influence of bribes of money or alcohol, and would misdiagnose some other disease as responsible for the death (Graunt, 1662: 24).

Before the onset of civil registration in 1837, relatives and friends of the deceased in London could therefore influence the reported cause of death by bribing, pressurizing or misinforming parish searchers. On the face of it, the poor would have been less able to influence returns in this way and were, therefore, less able to resist stigmatizing reports. The ability to control the process by which the cause of death was recorded must sometimes explain the clear social biases in the reporting of particular conditions noted above.

\section{Lunatics dying in London's public hospitals}

The number of lunatics dying in London's two public hospitals for the insane did not account for the fluctuations in the numbers reported in the Bills. Figure 2 shows that even if all lunatics from St Luke's found their way into the Bills, that hospital could not have fuelled either the overall number of lunatics returned, or the increase in lunatic mortality from the late eighteenth century. Simultaneously, a decreasing number of lunatics from Bethlem died over the eighteenth century. An average of 36 lunatics per year died at Bethlem during 1743-62, 28 p.a. in the following 20 years, 10 p.a. during 1783-1802, just 6 p.a. during 1803-1822 and 11 p.a. during 1823-42. Many of these died from a range of conditions, including infectious diseases such as smallpox (Webster, 1843; see also Andrews, Briggs, Porter, Tucker and Waddington, 1997: 340-1). The marked growth 


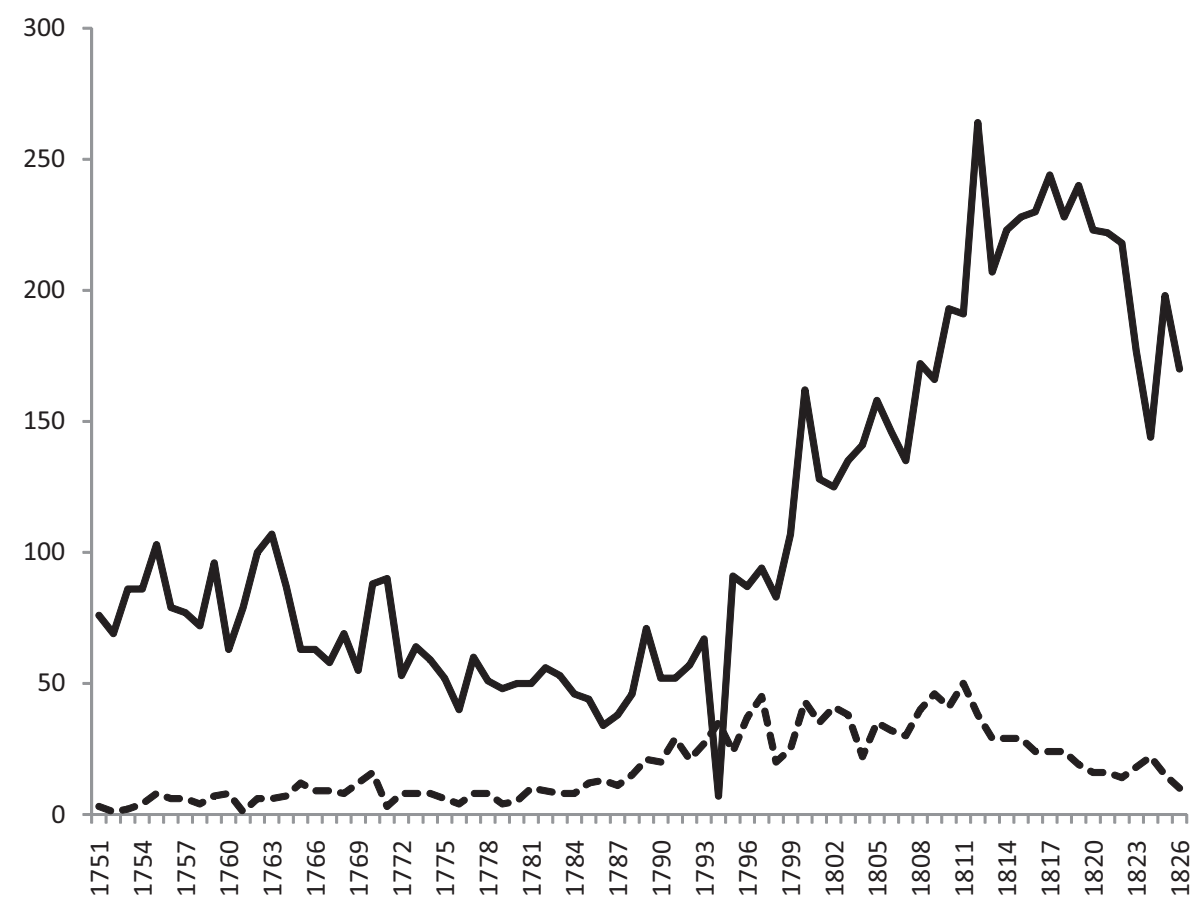

Figure 2. Numbers of deaths from St Luke's Hospital I75I-I826 (broken line; sources: LMA, BBR, I747-I809; LMA, BR, I807-I826) and caused by 'Lunacy' in the London Bills of Mortality (solid line; source: Marshall, I832)

in lunacy in the London Bills after the 1780s was caused by deaths from private madhouses. Their number grew significantly in this period, with 17 licensed madhouses in London in 1806 and 24 by 1816. Most parish pauper lunatics were kept in four large private madhouses (Green, 2010:152; Murphy, 2001a: 272-6). The numbers returned in the Bills depended on the extent to which lunacy was returned as cause of death by metropolitan parishes, but often these were unclear and were influenced by the social status of those returned lunatic. We need to examine the distorting filters which intervened between the incidence of lunacy at death, and a parish searcher's final return.

\section{Treatment of the lunatic poor in the parishes: St Martin in the Fields case study}

Many of those who died as lunatics were cared for through private funding provided by family or friends, rather than at the expense of the parish authorities. Although impossible to count accurately, private provision for lunatics was the norm. Those cared for at the expense of the parish were only a minority of the lunatic population. This distinction is important. Those who were buried as lunatics, or were insane towards the end of their life, comprised both parish paupers and also the much larger group of the privately-funded insane. Private patients are far less visible in the eighteenth-century records. ${ }^{8}$ The majority of those reported as dying of their lunacy were pauper lunatics. Between 1747 and 1824 in St Martin in the Fields, of 112 individuals buried as lunatics, 61 were paupers. Almost all of these (57) were buried from the workhouse. The true proportion of paupers is actually higher than this. The parish began sending most of its poor to a new burial ground in Camden Town after 
1806, and the registers of that place do not supply cause of death or burial fee. If the above figures are adjusted for the omission of Camden Town burials, 43 lunatics were charged for their burial, therefore not paupers, and 61 were paupers, suggesting that no less than 58.7 per cent of all those dying as lunatics were buried at parish expense in the eighteenth century. Pauperism and workhouse residence was thus associated very strongly with an ascription of lunacy at burial. As expected, it was the poor, especially the workhouse poor, who most lacked the ability to defend their relatives from shaming or stigmatizing labels at burial. Many of these lunatics, too, might have lacked available kin or 'friends' who might otherwise have seen to their burial. ${ }^{9}$ We thus need to know more about the experience of the insane parish pauper in St Martin's, and in particular the extent to which lunacy was ascribed as a cause of death to individuals who died during their insanity. St Martin's treatment of pauper lunatics seems fairly typical of other parishes in the metropolis (Murphy, 2001b: 411-26).

Throughout the eighteenth and early nineteenth centuries the parish sent relatively few pauper lunatics to London's public hospitals for the insane: Bethlem (occasionally Bedlam in the parish records) and St Luke's (opened 1751). Pauper lunatics were cared for in the workhouse, relieved as outdoor poor, boarded-out to people to whom they had no family ties, or their care was contracted out to a series of large private madhouses which served the London area (Murphy, 2001b; Suzuki, 1992).

Like most London parishes, St Martin's parish contracted with a series of private madhouse keepers in the eighteenth and early nineteenth centuries. Between 1728 and March 1746 the St Martin's workhouse discharge registers record sending paupers to 'Dr Wrights' who kept a private madhouse in Bethnal Green (COWAC, OA, 1727-28: 292, 297; see also Andrews and Scull, 2003: 9-11, 121 n.10, 160 n.30). From 1746 to 1751 lunatics were sent to a 'Mrs Wright', Dr Wright's widow. Between 1751 and 1755 no proprietor at Bethnal Green is listed. From 1755 a Mr Robert Cope, who took over the running of the Bethnal Green private madhouse from Mrs Wright, is listed as taking in parish lunatics (Andrews and Scull, 2003: 160, n.30). From 1765 to 1776 surviving accounts show that the parish paid well over 100 pounds a year to Cope to care for pauper lunatics, a service he is known to have performed for many parishes in the metropolitan area. In 1776 the parish ceased sending lunatics to Cope's (COWAC, OA, 1765-68; 1771-76). ${ }^{10}$ Instead it began sending its lunatics to Mr Harrison's at Hoxton. Harrison cared for parish lunatics until 1784, when, in an unusual move which reflected the growing capacity and medicalization of the workhouse, and probably a desire to save money, all parish lunatics were brought back from Harrison's and cared for in-house. On 25 Mar. 1784, for example, at least 14 lunatics were returned from Harrison's to the workhouse. ${ }^{11}$ Until the first few years of the nineteenth century very few paupers were sent to private madhouses from the workhouse (COWAC, OA, 1797, 1801). There was some limited use made of Bethlem and St Luke's during this period of workhouse provision. In 1805 there was a reversal of this policy, with the more recalcitrant and difficult lunatics sent, initially, to a private madhouse run by a Mr Turney and after 1805 to the large private madhouses run by 'Messrs. Warburton \& Co. of Bethnal Green', with 166 pauper lunatics sent to Warburton's from the workhouse between 1805 and 1824 (Boulton and Schwarz, 2012; Murphy, 2001a: 250-6). Lunatics sent by the parish for treatment were monitored by the parish authorities throughout the eighteenth century, with regular sums expended on visits, clothing and tips to servants. On occasion, expert medical help was brought in by the parish to confirm a diagnosis of insanity (COWAC, OA, 1790; also Suzuki, 1998: 155).

The next section analyses the role the workhouse played in the care and treatment of pauper lunatics, how lunatics were disposed of post-mortem, and what causes of death were ascribed to the 
dead insane; it also identifies the factors that helped to obfuscate the reporting of lunacy as a cause of death by the parish authorities.

Contemporary doctors and physicians were aware that lunacy was an uncertain diagnosis. Lunacy was often an intermittent state. Those labelled lunatic, mad or insane might recover or be 'cured'. Lunacy might not be treated as a valid cause of death, the condition might be covered up or an alternative diagnosis might be applied by searcher, doctor, friend or relative (Black, 1789: 136-40; see also: Andrews, 1991; Andrews and Scull, 2003: 58-81). Thus, the insane Londoner might not always appear in the historical record or, if so, was only sporadically labelled as insane. This means, of course, that the incidence of lunacy must always be understated in the historical record. However, the experience of lunacy may be best understood over the life-course. Case studies of known pauper lunatics in St Martin's are therefore a good way to illustrate the various factors that influenced the labelling of lunatics at death in the eighteenth century.

Steventon Withers (1705-65), a 46-year-old impoverished 'taylor' with a parish settlement in St Martin in the Fields (COWAC, SEB, 1750-1: 181), was first admitted to the parish workhouse in October 1750. From this date until October 1757, he was an inmate of the workhouse 11 times. A pattern was established of Steventon being sent to, or returned from, what was certainly a private madhouse in Bethnal Green, in which he often stayed for substantial periods. However, it was only on his admittance to the workhouse in October 1757, his eleventh admission, that he was labelled in the workhouse register as a 'lunatick'. After staying for over two years in the workhouse, he was again 'sent to Mr Robert Cope at Bethnal Green' in December 1759. His twelfth and last stay in the workhouse seems to have been his longest. Admitted (without any label of lunacy) in February 1761 at the age of 55, he seems to have stayed there for about four years until his death in February 1765. Withers was buried from the workhouse at the stated age of 59 in February 1765 with a cause of death ascribed to 'drop[sy]' (COWAC: ALPW, 1746-5: 276-86; 1752-58: 73, 76, 185; $1757-$ 63; BB, 1755-67; COA, 1726-27: 55; 1755-60: 55).

MacDonald and Murphy (1990: 121-5, 133, 365) have observed that by the latter decades of the eighteenth century Coroners' Juries described the overwhelming majority of those who took their own lives as being lunatics. The Westminster Coroners' Inquests, which survive complete from 1760 , commonly ascribed lunacy to virtually all those who committed suicide. ${ }^{12}$ These cases can be linked to the relevant individuals in St Martin's. In only a handful of such cases, however, was the legal verdict of insanity recorded by the parish searchers. In a few cases, both sources agreed on lunacy. Joseph Bladzer, said to be a teenager at his death in 1760 and returned as a 'lunatick' by the parish searchers, was reported to have hanged himself in a cellar in Long Acre, 'not being of sound Mind Memory and understanding but Lunatick and Distracted' (COWAC, BB, 1755-67; COWC, CI, 14 Feb.-31 Dec. 1760).

Most of those buried as lunatics in the parish did not have their deaths investigated by a coroner. This suggests that such lunatics were not suicides and that the circumstances of their deaths were not seen as suspicious or unexpected. Only 9 out of 112 deaths of lunatics listed in the Sexton's books are recorded as involving a Coroners' Warrant, compared with 53 out of 68 cases of suicide. Those killing themselves included just 5 cases where the searcher returned individuals who had 'hanged themselves being lunatic' (COWAC: BB, 1755-67; SDB, 1747-55). Although most of those who were identified as committing suicide were routinely described as lunatic by Coroners' Juries, relatively few suicides were returned as lunatics by the parish searchers.

It is not always clear why a return of lunacy by the searchers was made in one case and not in another. Henry Danker aged 69, 'a Dane', was admitted to the parish workhouse on 4 Aug. 1761. After a stay of seven months he died on the 14 Mar. 1762; the discharge register noted that 'he was found hanging in Mr. Paul Chatain's Stable in Castle street (Corn-chandler)'. At his interment on 
19 Mar., the searchers recorded that he hanged himself (COWAC: ALPW, 1757-63: 168; BB, 1755-67). Possibly financial problems had provoked Danker's suicide. The coroners' jury found that Danker had 'Hanged himself, being a Lunatick'. A witness who found the body reported that he had known 'the deceased about half a year and appeared to [the] Deponent to be of a Melancholly Disposition'. Another witness who had known him for five years confirmed the mental effects of Danker's social descent. Paul Chatain had had the impoverished Danker admitted to the workhouse, and noted he 'was disordered in his Mind on Account of his unhappy Circumstances'. Henry Smith, a workhouse servant, confirmed Danker's lunacy throughout his 10-month stay in the workhouse (COWC, CI, 8 Jan. 1762 - 20 Dec. 1762). However, no reference to lunacy was made by the parish searchers when reporting his cause of death. Perhaps the fact that Dankers had significant social connections and had been respectable led to the concealment of his lunacy.

\section{Place of death and place of burial of pauper lunatics}

Our case studies suggest the messy historical context that lay behind any one diagnosis of lunacy as cause of death. A key question is where were the parish lunatics actually buried. Of the 112 individuals labelled as lunatics at their burial in the parish, 14 were stated to have been brought back to the parish for burial from other places: 5 were brought back from Bethnal Green, probably mostly from private madhouses, 3 from Shoreditch (which contained Harrison's madhouse at Hoxton) and 6 from other metropolitan parishes. These figures undercount the amount of "extra local' lunatic deaths. Corpses of pauper lunatics who died at private madhouses were sometimes returned direct to the workhouse and then recorded as having died at that institution. Thus for example, Rosamond Alton a 28-year-old 'lunatic' admitted to the workhouse in August 1769 was 'sent to Mr. Copes ye following Day'. Her discharge entry was later annotated to the effect that she 'Died 29 Janry 1771', presumably at Cope's. Rosamond was never formally readmitted to the workhouse. Nonetheless her burial, supposedly from the workhouse, was recorded in the local sexton's books without any cause of death at all (COWAC: ALPW, 1764-69: 10; SDB, 1771-72). More straightforward was the case of the 36-year-old John Pratt. Admitted for the only time to the parish workhouse on 21 July 1783, he was 'Sent to Mr Harrison at Hoxton 25th July 83, Died Augt $23 / 83$ '. His burial entry on 26 Aug. 1783 duly records him as dying a lunatic at parish expense, and his given residence (very unusually) was said to be in the 'Madhouse, Workhouse' (COWAC: ALPW, 1782-87: 265; SDB, 1779-84).

Since the workhouse discharge registers give the details of 75 individuals who were discharged to hospitals and madhouses and subsequently died there, it is possible to determine the extent to which such in-patients were returned for local interment. Contrary to what one might suppose, almost all those sent from the workhouse and who died at private madhouses before the end of the eighteenth century were returned for local burial. In most cases they were returned as 'from the workhouse'. Without the workhouse discharge register, in other words, there would be no evidence that these individuals had died in a hospital. Of 45 workhouse inmates sent to a madhouse, and who were stated to have died there before 1805, 40 ( 89 per cent) can be found in the Sexton's books in the appropriate place. Most of those dying in private madhouses were brought back for local interment, and this probably applies to most of those dying in London's public hospitals as well. ${ }^{13}$ All this changed after 1805: not one of 30 paupers sent to private mad farms, and noted to have died there, seems to have been returned for local interment. Further work on the parish register of St Matthew Bethnal Green tells us more about the interment of madhouse inmates during this period. Very few lunatics can be found buried from local madhouses in the Bethnal Green parish register in the eighteenth century. However, from 1813 a staggering 15 per cent of all burials listed in the parish register were from local 
madhouses. In total there were no less than 912 dead lunatics interred out of 6038 burials recorded in the St Matthew Bethnal Green register between 1813 and 1825. If in all these cases lunacy as cause of death was returned to the London Bills, Bethnal Green alone would have contributed just under one-third of all those who were recorded as having died from lunacy in this period

It may be, too, that those sent to public hospitals for the insane (St Luke's and Bethlem) were far less likely to be returned to their home parish for interment. The greater majority of those who died insane in Bethlem before 1677 were buried in the Bethlem Churchyard in St Botolph Bishopsgate, and after that date, when the hospital moved to Moorfields, dead patients were interred in the New Bethlem Churchyard at St Stephen's Coleman Street (Andrews, 1991: 499-505). The Sexton's burial books show no person was apparently returned for burial from either of London's public hospitals for the insane, even though a handful of parish paupers are known to have died there. Just one workhouse inmate, George Baker, was recorded as having been brought back dead from Bethlem (in 1798) after being admitted to the workhouse insane in September of that year. He was recorded only as a workhouse inmate at his pauper 'lunatic' interment in November (COWAC: ALPW, 1795-1811: 23, 26; SDB, 1797-1803: 241). Of 11 St Martin's lunatics listed in the St Luke Hospital 'Curables' book and discharged as having died, links can only be made to two interments in St Martin's. Both were private patients; one was said to have died of 'fever' and the other was carried out of the parish for burial without any cause of death given. Neither entry mentioned St Luke's. Neither the rest of the 'curable' patients, whether private or pauper, nor the four private 'incurables' of St Martin's who died at the hospital, seem to have been returned to the parish for interment (LMA: CMB, 1750-74; CPB, 1751-1826). It would appear that, as Andrews (1991: 499-505) has observed, parishes paid hospitals to bury the insane dead, though the bodies of private patients were more likely to be recovered.

How were pauper lunatics treated in the parish, and what can we learn about their causes of death? Since we have just over 400 cases where lunatics were explicitly admitted to the workhouse, the question obviously arises as to how many who died following their admission were returned as lunatics by searchers. Readers should note that the workhouse admission books do not give reasons for admittance for most paupers admitted to the institution. For this reason many lunatics were probably not identified as such on admission. However, given the intermittent nature of the condition in the majority of cases, it is best not to inflate the existing figures with those re-admitted after a spell in a private madhouse or those known to have been lunatics at other times in their life-course. In some cases lunacy only became apparent after admission, and sometimes it was a response to admission.

To establish what known lunatics were reported to have died of, two linkage exercises were carried out. The first (see Table 1) matched those admitted as lunatics who subsequently died from the workhouse to available burial records (in the period 1747-1824 this was limited to 45 cases). Of the 45 potential links, only 12, just over a quarter, were described as lunatics at interment; 5 of the remaining 33 seem to have been buried outside the parish; 8 had no causes of death and the remainder died from a range of causes from smallpox, to fever, dropsy, consumption and cancer. The symptoms of some fevers and those associated with lunacy, of course, could be mistaken in the seventeenth- and eighteenth-century medical mind (Graunt, 1662: 22; see also: Andrews, 1991: 503; Macdonald, 1981: 145-8).

The second exercise (Table 2) matched those stated to have died in private madhouses to the same local burial register. Again, lunacy was only given as a cause of death for about a quarter of those parishioners dying in such institutions. Others died of consumption, fever, dropsy and so on. One, a 20-year-old woman, died in childbed. This suggests that the number of those dying in a lunatic state returned in the Bills should be multiplied by four to get at the true incidence of insanity at or around the point of death. This is clearly strong evidence that Graunt and other 
Table I. Causes of death of those admitted to the workhouse as lunatics and subsequently dying there (data from COWAC, SDB, I747-18I2)

\begin{tabular}{lc}
\hline Standard cause of death & No. deaths \\
\hline Aged & 3 \\
Cancer & $\mathrm{I}$ \\
Consumption & 5 \\
Dropsy & 4 \\
Fever & 4 \\
Lunacy & 12 \\
Missing & 5 \\
Not given & 8 \\
Smallpox & 1 \\
Sudden death & $\mathrm{I}$ \\
Suicide & $\mathrm{I}$ \\
Total & 45 \\
\hline
\end{tabular}

Table 2. Causes of death of those who were said to have died in madhouses 1747-1812 (data from COWAC, SDB, I747-1812)

\begin{tabular}{lc}
\hline Standard cause of death & No. deaths \\
\hline Asthma & 1 \\
Childbed & 1 \\
Consumption & 8 \\
Dropsy & 3 \\
Fever & 10 \\
Inflammation & 1 \\
Lunacy & 11 \\
Not given & 5 \\
Total & 40 \\
\hline
\end{tabular}

contemporaries were quite correct. Those dying, and reported as lunatics, grossly underestimate the number of those who actually died in that state (Black, 1789: 128-9; Graunt 1662: 22).

\section{Conclusion: lunacy, social status and the rise of the lunatic at death}

The apparently simple label of lunacy as cause of death returned by London's searchers, and recorded in the Bills of Mortality, hides a complex story. It is likely that the bulk of those returned were paupers, buried from London's public hospitals and particularly from its increasing number of private madhouses. Detailed analysis revealed often contradictory paths to a label of lunacy at death. Social status and the possession of some wealth tended to mean, at least for some of the deceased, that lunacy might be concealed at death - 'intentionally suppressed' as Black (1789: 128-9) suspected - and reported as something else. It was comparatively rare for those committing suicide to be reported as lunatics, despite the relative universality of coroners' verdicts to that effect. Many of those dying lunatic, as contemporaries were well aware, were reported to have been killed by other diseases and conditions. Our figures suggest that only a quarter of those dying lunatic actually had lunacy ascribed as a cause of death by parish searchers.

Over time, lunacy as cause of death was reported more frequently in the London Bills (Black, 1789: 128). In particular, there was a dramatic surge in reported lunacy towards the end of the eighteenth century. This latter must reflect the growth of private madhouses in the metropolitan area at that time and a growing readiness to return deaths of their patients as lunatics. Also, although we have limited evidence of this at present, it might well be that more of those dying as lunatics were being interred in the parish where they died rather than being returned to parishes. Those dying from madhouses in Bethnal Green might all have been returned as lunatics to the Bills. The surge in lunacy in the London Bills towards the end of the eighteenth century might also reflect a greater toleration and understanding of lunacy as a condition and a consequent diminishing hostility to the application of that term as a cause of death, but further research would be needed to establish this. 


\section{Notes}

1 For the life of John Graunt, see the Oxford Dictionary of National Biography Online article no. 11306 (accessed 4 Sep. 2011).

2 The quote in the title of this article is from the same page.

3 For the life and career of Dr William Black, see Oxford Dictionary of National Biography Online article no. 2498 (accessed 4 Sep. 2011).

4 For details of this project, sponsored by both the ESRC and the Wellcome Trust, see: http://research.ncl. ac.uk/pauperlives/.

5 Black, 1789: 244; Maitland, 1739: III, 537; see also Richardson, 1987: 30-72.

6 See: COWAC: OA, 1782, 1785: 178; SCA, 1773-74: 17; 1777-78: 18; SDB, 1797-1812; see also: Munkhoff, 1999; Siena, 2011.

7 See also remarks by Thomas Birch, 1759: 7.

8 In the entire period $17.5 \%$ of admissions to St Luke's were parish paupers and $82.5 \%$ were private patients; LMA, CPB, 1751-1826.

9 See Richardson, 1987: 125-6.

10 Murphy (2001a: 250) states that Wright's business was sold to one George Potter in 1755, and makes no mention at all of Cope.

11 See COWAC: ALPW, 1782-1787: 107, 288, 307, 394; 1787-1795: 15, 63, 372; 1795-1811: 1, 125, 376; also OA, 1782.

12 See also Black (1789: 128) for discrepancies between coroner's inquest verdicts and searcher's reports in the Bills.

13 Of St Martin's paupers dying in London's public hospitals, $87 \%$ were returned to the parish for burial.

\section{References}

Primary sources

Birch T (1759) A Collection of the Yearly Bills of Mortality, from 1657 to 1758 inclusive. London: A. Millar. Black W (ed.) (1789) An Arithmetical and Medical Analysis of the Diseases and Mortality of the Human Species, 2nd edn. London: J. Johnson.

Burn R (1767) Ecclesiastical Law. Vol. 4, 2nd edn. London: A. Millar.

City of Westminster Archive Centre (COWAC):

St Martin in the Fields Alphabetical List of Paupers in the Workhouse [ALPW]1746-1753 COWAC F4007; 1752-1811 COWAC F4008, F4022, F4075-80.

St Martin in the Fields Burial Book [BB] 1755-1767 COWAC F2469.

St Martin in the Fields Churchwardens' and Overseers' Accounts [COA] 1726-1727 COWAC F462; 1755-1760 COWAC F2225.

St Martin in the Fields Overseers' Accounts [OA] 1727-1728 COWAC F467; 1765-90 COWAC F54797; 1797 COWAC F611; 1801 COWAC F61.

St Martin in the Fields Senior Churchwardens' Account Book [SCA] 1773-74 COWAC F167; 1777-78 COWAC F164.

St Martin in the Fields Settlement Examinations Book [SEB]1750-1751 COWAC F5041; 1765-1766 COWAC F5054; 1775-1777 COWAC F5063; 1783-1784 COWAC F5069.

St Martin in the Fields Sexton's Day Book [SDB] 1747-1812 COWAC Accession 419/233-42.

COWC, see Westminster Abbey Muniment Room.

Graunt J (1662) Natural and Political Observations Mentioned in a Following Index, and Made upon the Bills of Mortality ... With Reference to the Government, Religion, Trade, Growth, Ayre and the Diseases of the Said City. London: printed by J. Martyn.

London Metropolitan Archives (LMA):

St Luke Hospital Old Street General Comittee Minute Book [CMB] 1750-1774 LMA H64/A/03/001.

St Luke Hospital Old Street House Curable Patients Books [CPB] 1751-1826 LMA H64/B/01/00-LMA $\mathrm{H} 64 / \mathrm{B} / 01 / 9$.

St Luke, Old Street Parish Baptism and Burial Registers [BBR] 1747-1809 P76/LUK/002/2-P76/LUK/007. St Luke, Old Street Parish Burial Register [BR] 1807-1827 P76/LUK/065-068. 
Maitland W (1739) The History of London, from its Foundation by the Romans, to the Present Time. London: printed by Samuel Richardson.

Marshall J (1832) Mortality in the Metropolis, a Statistical View of the Number of Persons Reported to have Died within the Bills of Mortality in Each of the Years, 1629-1831 with Accounts of the Amount Expended for the Maintenance of the Poor, etc. London: Treuttel, Würtz and Richter.

Webster J (1843) Statistics of Bethlem Hospital, with remarks on Insanity. Medico-Chirurgical Transactions 26: $374-416$.

Westminster Abbey Muniment Room: London Lives, 1690-1800 (transcribed on: www.londonlives.org; accessed 18 Jan. 2011): City of Westminster Coroners [COWC]: Coroners' Inquests [CI] into Suspicious Deaths:

14 Feb.-31 Dec. 1760 WACWIC652000003.

8 Jan. 1762 - 20 Dec. 1762. WACWIC652020030-37.

8 Jan. 1762-20 Dec. 1762. WACWIC652020232-238.

Secondary sources

Andrews J (1991) Bedlam revisited: history of Bethlem Hospital c.1634-1770. Unpublished PhD thesis, Queen Mary and Westfield College, University of London.

Andrews J, Briggs A, Porter R, Tucker P and Waddington K (1997) The History of Bethlem. London and New York: Routledge.

Andrews J and Scull A (2001) Undertaker of the Mind. John Monro and Mad-Doctoring in EighteenthCentury England. Berkeley and London: University of California Press.

Andrews J and Scull A (2003) Customers and Patrons of the Mad-Trade. The Management of Lunacy in Eighteenth-Century London, with the Complete Text of John Monro's 1766 Case Book. Berkeley and London: University of California Press.

Bonfield L (1997) Testamentary cases in the Prerogative Court of Canterbury, 1660-96. In: Brooks CW and Lobban M (eds) Communities and Courts in Britain, 1150-1900. London: Hambledon Press, 133-154.

Boulton JP and Schwarz LD (2012) The parish workhouse, the parish and parochial medical provision in eighteenth-century London. In: King S and Gestrich A (eds) Narratives of Sickness and Poverty in Europe. London: Clio Medica/The Wellcome Series in the History of Medicine, forthcoming.

Dobson MJ (1997) Contours of Death and Disease in Early Modern England. Cambridge: Cambridge University Press.

Green DR (2010) Pauper Capital. London and the Poor Law, 1790-1870. Farnham, UK: Ashgate.

Houlbrooke R (1998) Death, Religion, and the Family in England, 1480-1750. Oxford: Clarendon Press.

MacDonald M (1981) Mystical Bedlam. London and New York: Cambridge University Press.

MacDonald M and Murphy TR (1990) Sleepless Souls. Suicide in Early Modern England. Oxford: Clarendon Press.

Munkhoff R (1999) Searchers of the dead: authority, marginality and the interpretation of plague in England, 1574-1665. Gender \& History 11(1): 1-29.

Murphy E (2001a) Mad farming in the metropolis. Part 1: A significant service industry in East London. History of Psychiatry $12: 245-282$.

Murphy E (2001b) Mad farming in the metropolis. Part 2: The administration of the old poor law of insanity in the City and East London 1800-1834. History of Psychiatry 12: 405-430.

Porter R and Rousseau GS (1998) Gout: The Patrician Malady. New Haven, CT, and London: Yale University Press.

Razzell PE and Spence C (2006) The hazards of wealth: adult mortality in pre-twentieth-century England. Social History of Medicine 19(3): 381-405.

Richardson R (1987) Death, Dissection and the Destitute. London: Routledge \& Kegan Paul.

Siena K (2004) Venereal Disease, Hospitals and the Urban Poor: London's "Foul Wards", 1600-1800. Rochester, NY: University of Rochester Press.

Siena K (2009) Suicide as an illness strategy in the long eighteenth century. In: Weaver J and Wright D (eds) Histories of Suicide: International Persepctives on Self-Destruction in the Modern World. Toronto: University of Toronto Press, 53-72. 
Siena K (2011) Searchers of the dead in long eighteenth-century London. In: Kippen K. and Woods L (eds) Worth and Repute: The Play of Gender in Late Medieval and Early Modern Europe. Toronto: Centre for Reformation and Renaissance Studies, 123-152.

Smith L (2007) Lunatic Hospitals in Georgian England, 1750-1830. London: Routledge.

Suzuki A (1991) Lunacy in seventeenth- and eighteenth-century England: analysis of Quarter Sessions records. Part I. History of Psychiatry 2: 437-456.

Suzuki A (1992) Lunacy in seventeenth- and eighteenth-century England: analysis of Quarter Sessions records. Part 2. History of Psychiatry 3: 29-44.

Suzuki A (1998) The household and the care of lunatics in eighteenth-century London. In: Horden P and Smith R (eds) The Locus of Care. Families, Communities, Institutions, and the Provision of Welfare since Antiquity. London and New York: Routledge, 153-175. 